\title{
Lactation Induction in a Commissioned Mother by Surrogacy: Effects on Prolactin Levels, Milk Secretion and Mother Satisfaction
}

\section{Indução da lactação em mãe por útero de substituição: efeitos na concentração de prolactina, produção láctea e satisfação materna}

\author{
Emilie Zingler ${ }^{1}$ Angélica Amorim Amato $^{2}$ Alysson Zanatta ${ }^{1}$ Maria de Fátima Brito Vogt ${ }^{1}$ \\ Miriam da Silva Wanderley ${ }^{1}$ Coríntio Mariani Neto ${ }^{3}$ Alberto Moreno Zaconeta ${ }^{1}$
}

${ }^{1}$ Department of Obstetrics and Gynecology, Hospital Universitário de Address for correspondence Emilie Zingler, MD, SQNW 111 BI I Apt Brasília, Brazil

2 Department of Pharmaceutical Sciences, Campus Darcy Ribeiro, 601-Noroeste, Brasília, Brazil 70686-745

Universidade de Brasilia, DF, Brazil

${ }^{3}$ Department of Woman's Health, Universidade Cidade de São Paulo, Universida de São Paulo, São Paulo, Brazil

Rev Bras Ginecol Obstet 2017;39:86-89.
Abstract
Keywords
- breastfeeding
- galactogogues
- pregnancy
- lactation
- prolactin
- surrogate mother

\section{Resumo}

Palavras-chave
- aleitamento materno
- galactogogos
- gravidez
- lactação
- prolactina
- mãe substituta

Case report of a 39-year-old intended mother of a surrogate pregnancy who underwent induction of lactation by sequential exposure to galactagogue drugs (metoclopramide and domperidone), nipple mechanical stimulation with an electric pump, and suction by the newborn. The study aimed to analyze the effect of each step of the protocol on serum prolactin levels, milk secretion and mother satisfaction, in the set of surrogacy. Serum prolactin levels and milk production had no significant changes. Nevertheless, the mother was able to breastfeed for four weeks, and expressed great satisfaction with the experience. As a conclusion, within the context of a surrogate pregnancy, breastfeeding seems to bring emotional benefits not necessarily related to an increase in milk production.

Relato de caso de mãe por útero de substituição, de 39 anos de idade, submetida a indução da lactação por exposição sequencial a drogas galactogogas (metoclopramida e domperidona), estimulação mamilar mecânica com bomba elétrica, e sucção pelo recém-nascido. O estudo teve como objetivo analisar os efeitos de cada etapa do protocolo na concentração sérica de prolactina, no volume de secreção láctea e na satisfação materna. A concentração sérica de prolactina e a produção láctea não apresentaram mudanças significativas. Entretanto, a mãe foi capaz de amamentar a criança por quatro semanas, e manifestou grande satisfação com a experiência. Como conclusão, no contexto de maternidade por útero de substituição, o aleitamento materno parece promover benefícios emocionais, não necessariamente relacionados ao aumento do volume de leite. received

May 30, 2016

accepted

December 19, 2016

published online

March 3, 2017
Copyright @ 2017 by Thieme-Revinter

Publicações Ltda, Rio de Janeiro, Brazil
License terms

10.1055/s-0037-1598641. ISSN $0100-7203$. (c) $(1) \$$ 


\section{Introduction}

Surrogate pregnancy is an assisted reproduction technique that involves a temporary uterus donation by another woman when pregnancy is not advised or even impossible. Since the intended mother was not exposed to the lactogenic hormones related to pregnancy, the mother-child dyad may not enjoy the benefits of breastfeeding. However, after the description of the successful induction of lactation in mothers by adoption, ${ }^{1-6}$ there has been interest in testing the feasibility of this intervention in mothers by surrogacy. Two previous reports of lactation induction in surrogate pregnancies described success by using galactagogue drugs administered in combination or sequentially with nipple mechanical stimulation, but the effects of each intervention on serum prolactin (PRL) levels and the volume of milk secretion have not been addressed. ${ }^{7,8}$ Herein, we report the case of a mother by surrogate pregnancy who underwent induction of lactation and had serum PRL levels, milk production and mother satisfaction analyzed.

Since we were aware of a single case of induction of lactation in the context of surrogate pregnancies, ${ }^{8}$ we searched the literature from January 1995 to July 2015 at the PubMed database using the search terms lactation induction, surrogate pregnancy and lactation adoption. We found seven additional studies that described protocols for the induction of lactation in non-puerperal women, ${ }^{1-8}$ one of which had been applied in mothers by surrogacy. - Table 1 shows a summary of these eight articles.

\section{Case Report}

A 39-year-old-woman, G1P1, with previous postpartum hysterectomy due to uterine atony and an ongoing surrogate pregnancy (28th week) was referred to the Obstetrics and
Gynecology clinics at Hospital Universitário de Brasília, because of her desire to breastfeed. She was a highly motivated woman, who had successfully breastfed her first child.

As the table shows, galactagogue drugs, nipple stimulation and suction by the newborn were used alone or in combination to promote milk production, but the relative contribution of each intervention has not been studied. Therefore, we chose to apply them sequentially and do serial measures of serum PRL levels to evaluate the isolated effect of each one. Basal serum PRL levels were determined, in addition to the investigation of other hypophyseal hormones (luteinizing hormone [LH], follicle-stimulating hormone [FSH], thyroid-stimulating hormone [TSH]) and infectious diseases liable to vertical transmission in breastfeeding (human immunodeficiency virus [HIV] and human T-cell lymphotropic virus [HTLV]). The patient then received oral metoclopramide, $10 \mathrm{mg}$ every 8 hours for 10 days, when she complained of fatigue and emotional lability, so metoclopramide was discontinued, and oral domperidone, $10 \mathrm{mg}$ every 8 hours, was started instead. We chose domperidone because it is less commonly associated with extrapyramidal symptoms than chlorpromazine and sulpiride. ${ }^{7}$ After 10 days, the pharmacologic stimulus was discontinued, and the woman began nipple stimulation with an electric pump ( 15 minutes at each breast, every 4 hours, excluding sleep hours). This was maintained for 39 days until childbirth. After this, the newborn was breastfed on demand, with the administration of formula milk after each breast suckling, with no other breast stimuli, be them pharmacologic or with the pump. Serum PRL levels were determined at days $10,22,39,57$, and 78 of the protocol (day 1: first day of the metoclopramide administration).

The study was approved by the Ethics Committee of Universidade de Brasília. The patient signed an informed consent form for participation in the study and publication of the data.

Table 1 Summary of the data from 8 studies describing protocols for induction of lactation in non-puerperal women

\begin{tabular}{|c|c|c|c|}
\hline Author/year & Intervention & Setting & Result \\
\hline Kramer $(1995)^{1}$ & 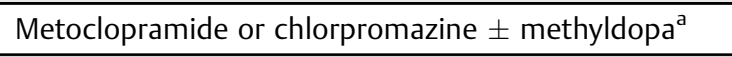 & Adoption & Successful \\
\hline Abejide et al $(1997)^{2}$ & $\begin{array}{l}\text { Manual nipple stimulation or } \\
\text { nipple stimulation with an electric pump }\end{array}$ & Adoption & Successful \\
\hline Cheales-Siebenaler (1999) ${ }^{3}$ & $\begin{array}{l}\text { Metoclopramide and nasal oxytocin, } \\
\text { simultaneously with nipple } \\
\text { stimulation with an electric pump }\end{array}$ & Adoption & Successful \\
\hline Biervliet et al $(2001)^{7}$ & $\begin{array}{l}\text { Metoclopramide simultaneously with } \\
\text { nipple stimulation with an electric pump }\end{array}$ & Surrogate Pregnancy & Successful \\
\hline Szucs et al $(2010)^{4}$ & $\begin{array}{l}\text { Domperidone for } 10 \text { weeks followed } \\
\text { by nipple stimulation with an electric pump }\end{array}$ & Adoption & Successful \\
\hline Shiva et al $(2010)^{8}$ & $\begin{array}{l}\text { Metoclopramide simultaneously with } \\
\text { mechanical nipple stimulation; } \\
\text { after childbirth, metoclopramide associated } \\
\text { with stimulation with an electric pump }\end{array}$ & Surrogate Pregnancy & Successful \\
\hline Wahlert and Fiester $(2013)^{5}$ & $\begin{array}{l}\text { Metoclopramide or chlorpromazine, } \\
\text { followed by nipple stimulation with an electric pump }\end{array}$ & Adoption & $\begin{array}{l}\text { Protocol } \\
\text { not completed }\end{array}$ \\
\hline Wilson et al $(2015)^{6}$ & $\begin{array}{l}\text { Domperidone simultaneously with nipple } \\
\text { stimulation with an electric pump }{ }^{\text {a }}\end{array}$ & Adoption & Successful \\
\hline
\end{tabular}

Note: ${ }^{a}$ Women who had never breastfed received previous breast tissue stimulation with hormonal contraceptives. 


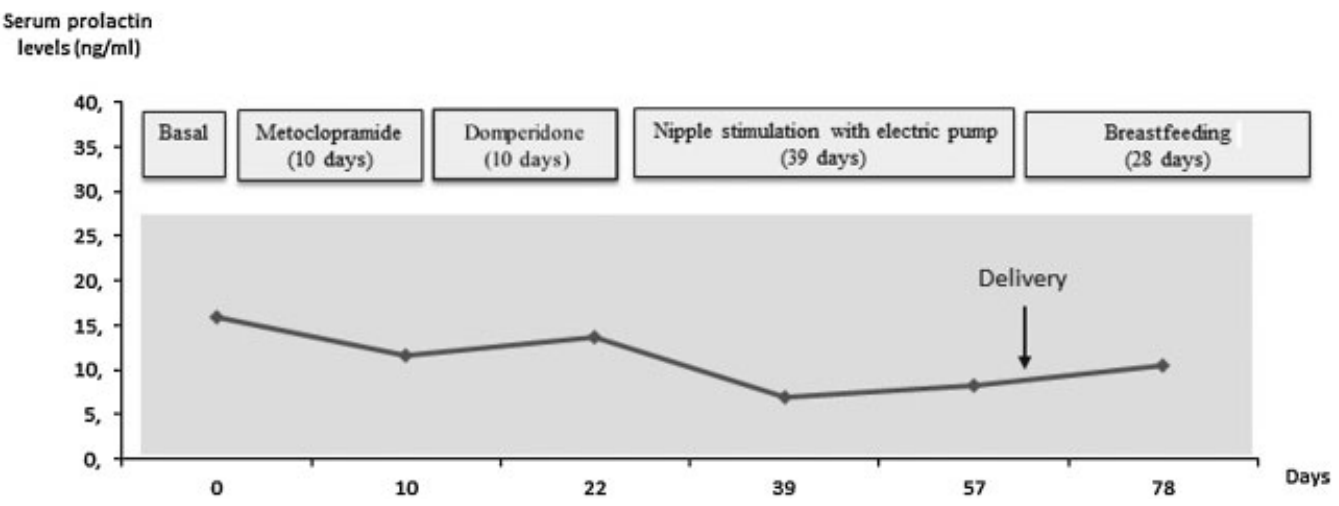

Fig. 1 Serum PRL levels over 78 days of induction of lactation. The shaded area represents the normal range of serum PRL levels ( $2.8 \mathrm{to} 29 \mathrm{ng} / \mathrm{mL})$.

Basal PRL levels remained within the normal range, with no changes over the study (-Fig. 1). Accordingly, nipple secretion was very scarce. Despite this and the need to feed the newborn with formula milk, the mother breastfed her child daily during 4 weeks. At the end of the protocol, when questioned about her feelings, she expressed great gratitude and satisfaction for having reached her goal of breastfeeding her child. She also emphasized the desire to share her "wonderful" experience with women in the same situation.

\section{Discussion}

We have described the case of a mother by surrogate pregnancy who underwent induction of lactation with dopaminergic antagonists for 20 days, followed by mechanical nipple stimulation during 39 days. This resulted in scarce nipple secretion and no change in serum PRL levels, but the mother breastfed for 4 weeks, and expressed great satisfaction with the result. To our knowledge, this is one of the few cases reported addressing the induction of lactation in mothers by surrogate pregnancy, and the first one in Brazil. In order to better understand the meaning of these findings, it is necessary to revisit some aspects of two previous studies. The first report describes the case of a woman in the United Kingdom who requested a surrogate pregnancy due to uterine agenesis. ${ }^{7}$ At the 28th week of the host pregnancy, she simultaneously received metoclopramide and nipple stimulation with an electric pump, which was maintained until 1 week before childbirth. At this moment, PRL levels were twice the upper limit of the normal range. The woman reported that milk was produced "easily", but in an insufficient amount to feed the baby, and, therefore, formula supplementation was needed. Breastfeeding was withdrawn after three months, and the woman showed great satisfaction with the experience. The authors emphasized the ease to induce milk production, and suggested that induction of lactation should be offered to every mother by surrogacy. ${ }^{7}$

In the second study, published nine years later, an Iranian woman who requested a surrogate pregnancy because of secondary infertility underwent induction of lactation before childbirth with a protocol similar to the one described, ${ }^{7}$ but metoclopramide and breast suction with the electric pump were maintained after childbirth. ${ }^{8}$ Serum PRL levels were not assessed, and the induction of lactation was considered successful because breastfeeding was maintained for three months, despite the use of formula supplementation due to the insufficient amount of milk production to meet the child's needs. The woman reported that breastfeeding propitiated a close contact with her child. ${ }^{8}$

At this point, it is interesting to ponder why studies addressing the induction of lactation in the setting of surrogacy are so scarce. ${ }^{7,8}$ Since surrogate pregnancies have been incorporated into the clinical practice over the last two decades, we could speculate that non-successful cases of induction of lactation may not have been reported, because the lack of description of negative results is common in scientific communication. ${ }^{9}$ It is also possible that interventions that successfully promoted mother satisfaction, but have not increased serum PRL levels or induced a significant amount of milk production, may have not been considered successful, and were therefore left unreported. This is possible because the real effectiveness of galactagogue drugs has recently been questioned. ${ }^{10}$ Although galactorrhea may be an adverse effect of the drugs that inhibit dopaminergic signaling, the effectiveness of these drugs in inducing galactopoiesis in non-puerperal women is not well established. ${ }^{10}$ We fear that the overly optimistic prescription of these drugs to induce lactation may result in suffering and frustration, especially in women who may have negative feelings for not having been able to experience pregnancy and labor.

In the present report, serum PRL levels exhibited no change in response to three interventions (anti-dopaminergic drugs, mechanical stimulation and suction by the newborn). Unlike the previous studies, we applied the stimuli sequentially and not combined, since our goal was to evaluate the effect of each one on serum PRL levels. In keeping with normal PRL levels, the nipple secretion was scarce, and we believe it was not milk, but an analysis of its composition was not performed. Despite the lack of clinical and biochemical data indicating the successful induction of lactation, the woman herein described the intervention as gratifying and successful, since she was able to breastfeed during four weeks with simultaneous feeding with formula milk. In our opinion, a crucial issue is to define what successful lactation induction within the context of surrogacy is. If the criterion for successful induction is sufficient milk production, the case 
reported herein should be considered unsuccessful, and the two previously reported cases partially successful, since formula supplementation was needed in both. ${ }^{7,8}$ The scenario is different if milk production is seen as a secondary goal of the lactation induction. In keeping with the latter idea, it has been suggested that the success of this intervention is mostly related to maternal feelings about breastfeeding, and secondarily to the amount of milk production or to the duration of breastfeeding. $7,8,11,12$

Understanding this idea is critical for the clinical practice, since mothers by surrogacy requiring induction of lactation should be properly advised to acknowledge the high probability of needing formula supplementation, and that the lack of milk production does not mean failure of the procedure. ${ }^{7,8,11}$ So, before initiating the protocol for inducing lactation, it should be emphasized that the intervention aims to offer the mother and the child the possibility to experience the emotional and affective benefits of breastfeeding, to consolidate the mother-child bond, and to allow the transfer of protective antibodies from the mother. It should be clearly stated that, in this setting, artificial milk can adequately supply the nutritional needs of the child. The training of health care providers regarding this is essential, since surrogate pregnancies are becoming frequent, and it is expected that an increasing number of women will demand them.

Finally, it may also be important to rethink the expression "induction of lactation" in the setting of surrogacy. If the main goal of inducing lactation in mothers by surrogacy is not necessarily to induce milk production, but to support and stimulate women so that they can benefit from the non-nutritional aspects of breastfeeding, then the terminology "induction of lactation" seems inappropriate. Therefore, we believe that the expression "promotion of breastfeeding" may be better to describe this procedure in mothers by surrogate pregnancy, and we suggest that it should be used in the clinical practice.

The promotion of breastfeeding seems to provide a highly rewarding experience in mothers by surrogate pregnancy, regardless of the amount of milk produced and of the need for formula supplementation.
Acknowledgments

The authors have no acknowledgments to make.

\section{References}

1 Kramer P. Breast feeding of adopted infants. BMJ 1995;311 (6998):188-189

2 Abejide OR, Tadese MA, Babajide DE, Torimiro SE, Davies-Adetugbo AA, Makanjuola RO. Non-puerperal induced lactation in a Nigerian community: case reports. Ann Trop Paediatr 1997; 17(02):109-114

3 Cheales-Siebenaler NJ. Induced lactation in an adoptive mother. J Hum Lact 1999;15(01):41-43

4 Szucs KA, Axline SE, Rosenman MB. Induced lactation and exclusive breast milk feeding of adopted premature twins. J Hum Lact 2010;26(03):309-313

5 Wahlert L, Fiester A. Induced lactation for the nongestating mother in a lesbian couple. Virtual Mentor 2013;15(09):753-756

6 Wilson E, Perrin MT, Fogleman A, Chetwynd E. The intricacies of induced lactation for same-sex mothers of an adopted child. J Hum Lact 2015;31(01):64-67

7 Biervliet FP, Maguiness SD, Hay DM, Killick SR, Atkin SL. Induction of lactation in the intended mother of a surrogate pregnancy: case report. Hum Reprod 2001;16(03):581-583

8 Shiva M, Frotan M, Arabipoor A, Mirzaaga E. A successful induction of lactation in surrogate pregnancy with metoclopramide and review of lactation induction. Int J Fertil Steril 2010;3(04): 191-194

9 Matosin N, Frank E, Engel M, Lum JS, Newell KA. Negativity towards negative results: a discussion of the disconnect between scientific worth and scientific culture. Dis Model Mech 2014; 7(02):171-173

10 Academy Of Breastfeeding Medicine Protocol Committee. ABM Clinical Protocol \#;9: Use of galactogogues in initiating or augmenting the rate of maternal milk secretion (First Revision January 2011). Breastfeed Med 2011;6(01):41-49

11 Schnell A. Breastfeeding without birthing: mothers through adoption or surrogacy can breastfeed!. J Hum Lact 2015;31(01): 187-188

12 Wittig SL, Spatz DL. Induced lactation: gaining a better understanding. MCN Am J Matern Child Nurs 2008;33(02):76-81, quiz 82-83 